\title{
Origin of Intact Lactoferrin and Its DNA-Binding Fragments Found in the Urine of Human Milk- Fed Preterm Infants. Evaluation by Stable Isotopic Enrichment ${ }^{1}$
}

\author{
T. WILLIAM HUTCHENS, JOSEPH F. HENRY, TAI-TUNG YIP, DAVID L. HACHEY, \\ RICHARD J. SCHANLER, KATHLEEN J. MOTIL, AND CUTBERTO GARZA?
}

USDA/ARS Children's Nutrition Research Center, Department of Pediatrics, Baylor College of Medicine and Texas Children's Hospital, Houston. Texas 77030

\begin{abstract}
The origin of intact (78-kD) lactoferrin found in the urine of human milk-fed preterm infants was investigated using human milk containing proteins enriched with $\left[{ }^{13} \mathrm{C}\right]$ leucine and $\left[{ }^{15} \mathrm{~N}_{2}\right]$ lysine or $\left[{ }^{2} \mathrm{H}_{4}\right]$ lysine. Mothers of infants selected for the study were infused i.v. with $\left[{ }^{13} \mathrm{C}\right]$ leucine and $\left[{ }^{15} \mathrm{~N}_{2}\right]$ lysine or $\left[{ }^{2} \mathrm{H}_{4}\right] l y s i n e$ to label milk proteins. The labeled milk was collected from each mother, pooled, fortified with a lyophilized human milk fraction, and fed to her preterm infant by continuous orogastric infusion for a period of $48 \mathrm{~h}$. Urine was collected from each infant for $96 \mathrm{~h}$. Intact lactoferrin (78 kD) and DNAbinding lactoferrin fragments $(51$ and $39 \mathrm{kD})$ were purified from the urine by affinity chromatography on columns of immobilized single-stranded DNA-agarose. The concentration and isotopic enrichment of the intact lactoferrin and DNA-binding fragments were determined separately after their isolation by high-performance reverse-phase (phenyl) chromatography. Mass spectral analyses indicated that the isotopic enrichment of the purified urinary lactoferrin was 87 to $100 \%$ of that in the labeled human milk lactoferrin. Similar results were obtained for the isolated DNA-binding lactoferrin fragments. The ratios of isotopically labeled leucine to lysine in the purified milk lactoferrins and urinary lactoferrins were similar for each mother/infant pair. Isotopically labeled lysine, added to the milk as free amino acid, was not incorporated into the purified urinary lactoferrin. These results demonstrate that undegraded (78-kD) lactoferrin of maternal origin is absorbed by the gut and excreted intact in the urine of preterm infants; nearly all of the urinary lactoferrin was of maternal origin. The possible immunoregulatory functions of the absorbed intact, maternal lactoferrin are discussed. (Pediatr Res 29: 243-250, 1991)
\end{abstract}

\section{Abbreviations}

APE, atom percent excess

GC-MS, gas chromatography-mass spectrometry

ssDNA, single-stranded DNA

Received July 24, 1990; accepted November 6, 1990.

Correspondence: $T$. William Hutchens, Department of Pediatrics (CNRC), Baylor College of Medicine, 1100 Bates, Houston, TX 77030

${ }^{1}$ This project has been funded, in part, with federal funds from the U.S. Department of Agriculture, Agricultural Research Service under Cooperative Agreement no. 58-7MN1-6-100 and NIH Grant 5RO1HD21049-05. The contents of this publication do not necessarily reflect the views or policies of the U.S. Department of Agriculture, nor does mention of trade names, commercial products, or organizations imply endorsement by the U.S. Government.

${ }^{2}$ Present address: Division of Nutritional Science, Cornell University, 127 Savage Hall, Ithaca, NY, 14850.
HEPES, $N$-2-hydroxyethylpiperazine- $N^{\prime}$-2-ethanesulfonic acid

PAGGE, polyacrylamide gradient gel electrophoresis

HFBA, heptafluorobutyric acid

Lactoferrin is a major constituent of human colostral milk and whey (1). This 78-kD secretory glycoprotein binds several different transition metal ions $(2,3)$, but is best characterized for its iron-binding properties and its association with host defense at mucosal surfaces (4). Perhaps more interesting are its postulated growth-promoting $(5,6)$ and immune-modulating properties (711). The structures of human hololactoferrin and apolactoferrin are known $(12,13)$, but their full biologic significance and mechanisms of action remain the subject of continued investigations.

Utilization of lactoferrin by the immature gastrointestinal system of preterm and term infants is poorly characterized. Infants fed human milk excrete higher levels of fecal lactoferrin than do infants fed bovine milk-based formulas (14-18). Fecal excretion, however, accounts for only a few percent $(1-6 \%)$ of the lactoferrin fed $(16,17)$, and most fecal lactoferrin is degraded to lower molecular mass forms (19-21). Investigators have also reported higher levels of lactoferrin and lactoferrin fragments, free secretory component, and secretory $\operatorname{IgA}$ in the urine of infants fed human milk than in the urine of infants fed a bovine milk-based formula $(21,22)$. The molecular sizes of these immune factors are larger than normally filtered by glomeruli (23). The serum levels of lactoferrin are similar in formula- and human milk-fed preterm infants $(0.8$ to $0.9 \mu \mathrm{g} / \mathrm{mL})(22)$. More recently, Scott $(24,25)$ has reported that the serum levels of lactoferrin in preterm infants are substantially higher than in term infants, and no difference was observed between term infants fed exclusively human milk and those fed bovine milk-based formula.

To determine the origin and quantify the relative urinary concentrations of intact lactoferrin and its fragments, simple and very efficient purification procedures are required. We have used immobilized DNA as an affinity method to purify human milk lactoferrin (26) as well as intact lactoferrin from the urine of human milk-fed preterm infants (27). We report here the stable isotope incorporation into human milk lactoferrin and its use to demonstrate the origin of intact lactoferrin, and of two relatively large (51- and 39-kD) lactoferrin fragments, present in the urine of human milk-fed preterm infants.

\section{MATERIALS AND METHODS}

Materials. $\mathrm{L}-\left[1-{ }^{13} \mathrm{C}\right]$ leucine and $\mathrm{L}-\left[2,6-{ }^{15} \mathrm{~N}_{2}\right]$ lysine- $\mathrm{HCl}$ or $\mathrm{L}-$ $\left[4,4,5,5-{ }^{2} \mathrm{H}_{4}\right]$ lysine- $\mathrm{HCl}$ (Merck Sharp and Dohme, Montreal, 
Canada) were assayed by GC-MS and were found to contain 99 APE ${ }^{13} \mathrm{C}, 96 \mathrm{APE}{ }^{15} \mathrm{~N}_{2}$, and $98 \mathrm{APE}$ deuterium, respectively. The isotopically labeled leucine and lysine were dissolved aseptically and individually in $0.9 \%$ sodium chloride and potassium phosphate buffer ( $\mathrm{pH} \mathrm{7.2)} \mathrm{to} \mathrm{concentrations} \mathrm{of} 15$ and $25 \mathrm{mg} / \mathrm{mL}$, respectively. The isotopic solutions were verified to be sterile and pyrogen free by standard culture plate techniques and Limulus amebocyte lysate assays (Pyrogent, Mallinckrodt, St. Louis, MO), respectively.

Selection of lactating women. Two healthy, lactating mothers of preterm infants (27-28 wk gestation) participated at 6 wk postpartum. Informed written consent was obtained from each mother. The study was approved by the Institutional Review Board for Human Research at Baylor College of Medicine and the Clinical Investigations and Publications Committee of Texas Children's Hospital. The mothers were admitted to the Texas Children's Hospital General Clinical Research Center for $3 \mathrm{~d}$. Medical histories and physical examinations were conducted before participation. The values for time postpartum, age, height, and weight of the subjects are shown in Table 1.

Maternal dietary intakes. Before admission, both women were interviewed by a research nutritionist to determine dietary intakes by 24-h dietary recall. The mothers were then given a controlled diet of protein and energy for $3 \mathrm{~d}$. This diet consisted of commercially prepared formula and pudding (Sustacal, Mead Johnson, Evansville, IN) designed to provide protein intakes of $1.0 \mathrm{~g} / \mathrm{kg} / \mathrm{d}$ and energy intakes that equaled each individual's usual dietary intake determined from the dietary recall (Table 1). To promote compliance, additional protein-free fruits and vegetables were added to the diet in an amount $<10 \%$ of the total daily energy intake. The subjects consumed four isocaloric, isonitrogenous meals at $0800,1200,1700$, and $2100 \mathrm{~h}$. Daily protein and energy consumption were determined from the differences in the weights of pre- and postmeal formula and pudding containers.

Maternal milk production. Maternal milk production was determined throughout the controlled dietary period. Milk samples were collected from both breasts in preweighed containers at 3$\mathrm{h}$ intervals by mechanical pumping (Egnell, Cary, IL). Total daily milk production was calculated from the differences in the preand postweights of the milk collection containers during the 3day study interval (Table 1). A weighed aliquot of milk was obtained from each milk expression and stored at $-20^{\circ} \mathrm{C}$ until fortification and further analysis for protein, lactoferrin, and energy concentrations.

Incorporation of isotopically labeled amino acids into milk proteins. A primed, constant infusion of $\left[{ }^{13} \mathrm{C}\right]$ leucine and $\left[{ }^{15} \mathrm{~N}_{2}\right]$

Table 1. Characteristics of mothers and infants evaluated in this study

\begin{tabular}{lcc}
\hline \multicolumn{1}{c}{ Characteristic } & Subject 1 & Subject 2 \\
\hline Mother & & \\
Age $(\mathrm{y})$ & 36.1 & 30.4 \\
$\mathrm{Ht}(\mathrm{cm})$ & 161 & 165 \\
Wt $(\mathrm{kg})$ & 68.3 & 65.5 \\
Protein intake (g/kg/d) & 1.0 & 1.0 \\
Energy intake (kcal/d) & 2085 & 2210 \\
Milk production (g/d) & 665 & 1467 \\
Milk (fortified) lactoferrin con- & $1.89 \pm 0.23$ & $2.95 \pm 0.20$ \\
$\quad$ centration (mg/mL)* & & \\
Infant & 28 & 27 \\
Gestational age (wk) & 1.20 & 0.86 \\
Birth wt $(\mathrm{kg})$ & 40 & 47 \\
Age at study (d) & 1.47 & 1.55 \\
Body wt at study (kg) & 161 & 153 \\
Milk (fortified) intake during & & \\
$\quad$ study (g/kg/d) & & \\
\hline
\end{tabular}

* Mean lactoferrin concentration ( \pm SD) of fortified human milk (3 pools of milk/subject). lysine (subject 2 ) or $\left[{ }^{2} \mathrm{H}_{4}\right]$ lysine (subject 1) was administered to both volunteer mothers for $48 \mathrm{~h}$. The isotopic solutions were administered i.v. via a peripheral hand vein as follows: $\left[{ }^{13} \mathrm{C}\right]$ leucine and $\left[{ }^{15} \mathrm{~N}_{2}\right]$ lysine or $\left[{ }^{2} \mathrm{H}_{4}\right]$ lysine, 5.5 and $3.2 \mu \mathrm{mol} / \mathrm{kg}$, respectively, as priming doses; and $\left[{ }^{13} \mathrm{C}\right]$ leucine and $\left[{ }^{15} \mathrm{~N}_{2}\right]$ lysine or $\left[{ }^{2} \mathrm{H}_{4}\right]$ lysine, 4.6 and $3.2 \mu \mathrm{mol} / \mathrm{kg} / \mathrm{h}$, respectively, as the infusion dose. The latter solution was infused by means of a calibrated infusion pump (model 960, IMED Instruments, San Diego, CA) at a rate of $19 \mathrm{~mL} / \mathrm{h}$. Milk samples were collected before, during, and after the period of stable isotope infusion. Aliquots of the milk samples collected at 3-h intervals over a 48$h$ period were used to evaluate the isotopic enrichment of leucine and lysine in lactoferrin. Aliquots of each of the pooled, fortified, and labeled milk samples were removed for purification of lactoferrin and the determination of its isotopic enrichment by GC-MS analyses.

Preterm infant feeding of labeled human milk. The labeled milk samples, collected from each mother during the 48-h infusion, were pooled and fortified (30\% of total nitrogen) with unlabeled lyophilized human milk powder prepared from our Human Milk Bank (28). Fortified human milk (29) was prepared daily by adding skim fractions (derived from pasteurized, lyophilized, mature, donor human milk) to fresh milk from each infant's mother. Free $\left[{ }^{15} \mathrm{~N}_{2}\right]$ lysine $(200 \mu \mathrm{g} / \mathrm{mL})$ or $\left[{ }^{2} \mathrm{H}_{4}\right]$ lysine $(100 \mu \mathrm{g} / \mathrm{mL})$ was added to the fortified, labeled milks of subjects 1 and 2 , respectively. The two preterm infants evaluated in this study were $28 \mathrm{wk}$ gestational age at birth and showed appropriate growth for gestational age. They were free of congenital abnormalities, and cardiopulmonary, infectious, and gastrointestinal disorders. Each preterm infant was tolerant to complete enteral feedings by $15 \mathrm{~d}$ of postnatal life and was fed (at $6 \mathrm{wk}$ of age) unlabeled fortified human milk for a minimum of 1 wk before the introduction of isotopically labeled human milk by continuous orogastric infusion $(150 \mathrm{~mL} / \mathrm{kg} / \mathrm{d})$ for $48 \mathrm{~h}$. This particular feeding protocol has been discussed fully (29). During the remaining $48 \mathrm{~h}$ of the study period, the infants continued to receive fortified human milk.

Collection of preterm infant urine and quantitation of lactoferrin and protein. The preterm infant urine was collected in 8-h pools for a 96-h period, which commenced with the onset of feeding labeled, fortified human milk $(20,21)$. Urinary lactoferrin levels were quantified by routine ELISA methods (30). Polyclonal antibodies directed against human milk lactoferrin (Dako Corporation, Santa Barbara, CA) were immobilized on a plastic 96-well microtiter plate. The urine samples with (positive controls) and without added lactoferrin were first incubated with the primary, immobilized antibody. A serial dilution of purified human lactoferrin (Jackson ImmunoResearch Laboratories, Inc., West Grove, PA) was also included on each microtiter plate. The plates were then washed to remove unbound reagents before incubation with a second anti-human lactoferrin antibody conjugated to horseradish peroxidase. The color reaction was developed with hydrogen peroxide in citrate buffer containing $\mathrm{O}$ phenylenediamine (Sigma Chemical Co., St. Louis, MO). Absorbance values were measured at $490 \mathrm{~nm}$. Urinary protein levels were assayed by the method of Smith et al. (31) using the bicinchoninic acid protein reagent obtained from Pierce (Rockford, IL).

Purification of the urinary lactoferrin by single-stranded DNAagarose affinity chromatography. Calf thymus ssDNA-agarose containing $0.61 \mathrm{mg} \mathrm{DNA} / \mathrm{mL}$ gel (lot no. 71101) was obtained from Bethesda Research Laboratory, Gaithersburg, MD. It was packed into a $1.5-\mathrm{cm}$ inner diameter column to a bed volume of $10 \mathrm{~mL}$. The column was washed with water and then equilibrated with $20 \mathrm{mmol} / \mathrm{L}$ HEPES at $\mathrm{pH} 7.0$ containing $3 \mathrm{~mol} / \mathrm{L}$ urea. The flow rate was maintained at $30 \mathrm{~mL} / \mathrm{h}$. The separation procedure was carried out at room temperature $\left(22\right.$ to $\left.25^{\circ} \mathrm{C}\right)$. Trace amounts of $\left[{ }^{125} \mathrm{I}\right]$-labeled human lactoferrin (prepared by the lactoperoxidase method of Marchalonis (32) using a kit from Bio-Rad, Richmond, CA) were added to a $20-\mathrm{mL}$ portion of 


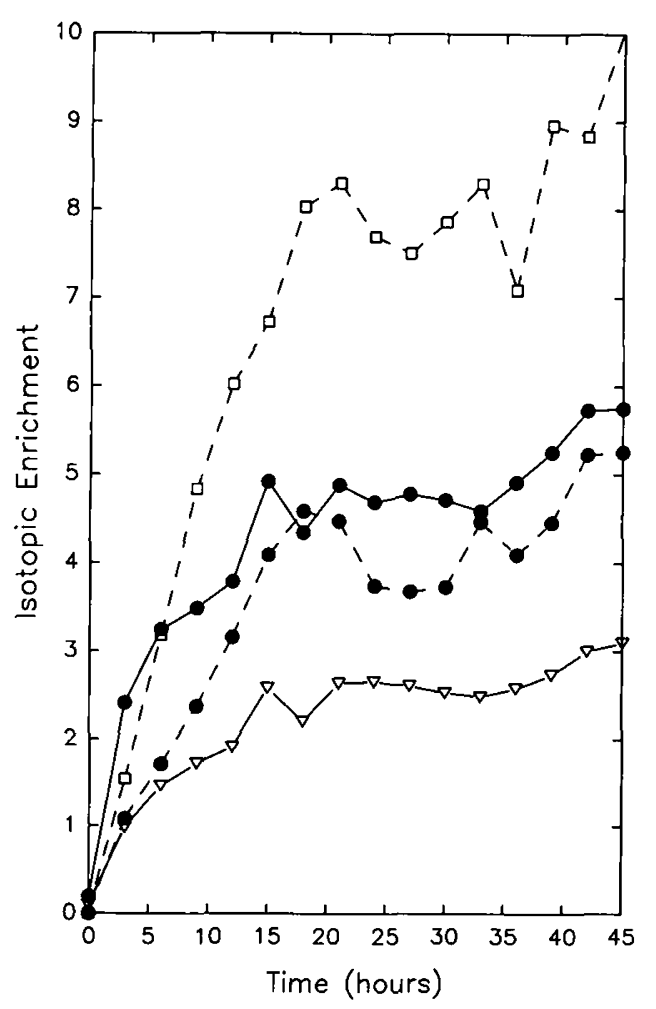

Fig. 1. Uptake of the stable isotopes $\left[{ }^{13} \mathrm{C}\right]$ leucine (filled circles) and $\left[{ }^{15} \mathrm{~N}_{2}\right]$ lysine (open triangles) or $\left[{ }^{2} \mathrm{H}_{4}\right]$ lysine (open squares) into purified human milk lactoferrin by subject 1 (dashed lines) and subject 2 (closed lines).

pooled preterm infant urine. After addition of urea to $3 \mathrm{~mol} / \mathrm{L}$ and $\mathrm{pH}$ adjustment to 7.0 , the urine sample was centrifuged $(1000 \times g$ for $10 \mathrm{~min})$ and the supernatant was loaded onto the ssDNA-agarose column. The column was then washed with 30 $\mathrm{mL}$ of $20 \mathrm{mmol} / \mathrm{L}$ HEPES buffer (pH 8.0) containing $6 \mathrm{~mol} / \mathrm{L}$ urea. Urea was subsequently eliminated by washing with three bed volumes of $20 \mathrm{mmol} / \mathrm{L}$ HEPES ( $\mathrm{pH} \mathrm{8.0)} \mathrm{buffer.} \mathrm{Elution} \mathrm{with}$ three bed volumes each of $0.2 \mathrm{~mol} / \mathrm{L}$ and $0.5 \mathrm{~mol} / \mathrm{L} \mathrm{NaCl}$ resulted in the elution of nonlactoferrin proteins and lactoferrin, respectively. Fractions of $2 \mathrm{~mL}$ were collected for determination of UV absorbance at $280 \mathrm{~nm}$ (Beckman model DU-70, Beckman Instruments, Fullerton, CA) and radioactivity (Packard Autogamma 5500, Packard Instrument Co., Inc., Downers Grove, IL). To regenerate the ssDNA-agarose column, it was washed with $8 \mathrm{~mol} / \mathrm{L}$ guanidine hydrochloride in $20 \mathrm{mmol} / \mathrm{L}$ HEPES ( $\mathrm{pH} 8.0$ ), followed by water. The purity of the isolated lactoferrin was evaluated by SDS-PAGGE and silver-staining, high-performance reverse-phase (phenyl) chromatography, high-performance ion-exchange (Mono-S) chromatography, and when possible, $\mathrm{N}$ terminal amino acid sequence analyses $(27,33)$.

$S D S-P A G G E$ of purified lactoferrin. The samples from the ssDNA-agarose column were concentrated (100- to 300 -fold) using a Centricon-10 (Amicon, Danvers, MA) centrifugal concentrator (10000 molecular wt cutoff). An aliquot of the concentrated sample (50 to $100 \mu \mathrm{L}$ ) was mixed with solubilizing buffer (50 $\mu \mathrm{L} 2 \%$ SDS with $3 \%$ mercaptoethanol) and heated in a boiling water bath for $90 \mathrm{~s}$. Electrophoresis on a 10 to $20 \%$ polyacrylamide separating gel with $4.5 \%$ stacking gel was performed essentially according to the method of Laemmli (34). After electrophoresis, the gel was fixed with $10 \%$ acetic acid in $50 \%$ methanol, then silver stained, with minor modifications, according to the method described by Morrissey (35). Low molecular weight markers (Pharmacia LKB Biotechnology Inc., Piscataway, NJ), including phosphorylase b $(94 \mathrm{kD})$, BSA $(67$ $\mathrm{kD}$ ), ovalbumin (43 kD), carbonic anhydrase (30 kD), soybean trypsin inhibitor (20.1 kD), $\alpha$-lactalbumin $(14.4 \mathrm{kD})$, and human milk lactoferrin $(78 \mathrm{kD})$ standard (Jackson ImmunoResearch Laboratories, Inc., West Grove, PA), were used to determine the molecular mass of the purified urinary lactoferrin.

High-performance reverse-phase chromatography. An aliquot $(50 \mu \mathrm{L})$ of the concentrated, purified lactoferrin sample obtained from ssDNA-agarose was applied to a Vydac TP2 19 (diphenyl) reverse phase column $(4.6 \mathrm{~mm} \times 25 \mathrm{~cm}, 5-\mu \mathrm{m}$ particle size, 300 $\AA$ pore diameter; The Separations Group, Hisperia, CA) and eluted with a linear gradient of 44.5 to $52.2 \%$ solvent $B$ in solvent A over 30 min (solvent A: $0.5 \%$ HFBA in Milli-Q (Millipore Corp., Bedford, MA) water; solvent B; 0.5\% HFBA in $100 \%$ acetonitrile). The flow rate was $1 \mathrm{~mL} / \mathrm{min}$ and protein elution was determined by UV absorbance at $280 \mathrm{~nm}$ (Beckman System Gold HPLC with a model 166 or 167 UV detector, Beckman Instruments).

Electrophoretic (Western) transfer and immunoblotting. SDSPAGGE was performed under denaturing conditions except that reducing agents were eliminated during sample preparation. Approximately $5 \mu \mathrm{g}$ protein were loaded to each well of the gel. Western transfer (36) was performed on nitrocellulose membranes (Bio-Rad) at $\mathrm{pH} 8.3$ in $0.025 \mathrm{M}$ Tris, $0.19 \mathrm{M}$ glycine, $20 \%$ methanol buffer at $30 \mathrm{~V}$ for $16 \mathrm{~h}$ at room temperature $(22$ to $25^{\circ} \mathrm{C}$ ). After $16 \mathrm{~h}$, the voltage was increased to $60 \mathrm{~V}$ for $1 \mathrm{~h}$. The nitrocellulose membranes were blocked for $1.5 \mathrm{~h}$ at $37^{\circ} \mathrm{C}$ with $0.1 \%$ gelatin (Bio-Rad) in $5 \mathrm{mM}$ Tris- $\mathrm{HCl}, 0.15 \mathrm{M}$ sodium chloride, $\mathrm{pH}$ 8.0. After blocking, the membrane was incubated for $1.5 \mathrm{~h}$ at $37^{\circ} \mathrm{C}$ with rabbit anti-human lactoferrin primary antibodies (purified Ig fraction) diluted in $5 \mathrm{mM}$ Tris- $\mathrm{HCl}$ ( $\mathrm{pH}$ $8.0), 0.15 \mathrm{M} \mathrm{NaCl}$, and $0.05 \%$ Tween-20. After incubation with the primary antibody, the membrane was washed three times, then incubated for $1.5 \mathrm{~h}$ at $37^{\circ} \mathrm{C}$ with diluted goat anti-rabbit IgG antibodies conjugated with horseradish peroxidase (BioRad). Color development was performed using 4-chloro-1-naphthol with hydrogen peroxide in methanol.

Mass spectrometry. The ${ }^{13} \mathrm{C},{ }^{15} \mathrm{~N}$, or deuterium enrichments of free leucine and lysine, respectively, were determined after ion-exchange chromatography by GC-MS (37). Samples of pure lactoferrin, isolated from mothers' milk and their infants' urine, were hydrolyzed in $500 \mu \mathrm{L}$ of $12 \mathrm{~N} \mathrm{HCl}$ for $14 \mathrm{~h}$ at $110^{\circ} \mathrm{C}$. The hydrolysates were evaporated to dryness, and converted to the n-propyl ester, $N$-heptafluorobutyramide derivative (38). GC-MS analyses of these derivatives were performed in triplicate on a Hewlett Packard HP-5988A quadrupole mass spectrometer (Palo Alto, CA) using the [M-HF] ${ }^{-}$ions produced by electron-capture negative ion GC-MS (39). Isotopic enrichment data are expressed as the molar ratio of isotopically labeled amino acid to unlabeled amino acid $(\times 100)$ after correction for natural abundance as described previously (39).

\section{RESULTS}

Incorporation of $\left[{ }^{13} \mathrm{C}\right.$ leucine and $\left[{ }^{15} \mathrm{~N}_{2}\right]$ lysine or $\left.{ }^{2} \mathrm{H}_{4}\right]$ lysine into milk lactoferrin. Figure 1 shows the rate and extent of stable isotopic enrichment of maternal lactoferrin purified from aliquots of the milk collected at 3-h intervals during the 48-h period of isotope infusion. All of the labeled milk collected from each subject during the 48-h period of isotope infusion was pooled and fortified with human milk powder. Enzyme-linked immunoassays indicated that these fortified pools contained 1.89 and $2.95 \mathrm{mg} / \mathrm{mL}$ lactoferrin (Table 1 ). The $\left[{ }^{13} \mathrm{C}\right]$ leucine and $\left[{ }^{2} \mathrm{H}_{4}\right]$ lysine enrichments of lactoferrin in the pooled, fortified human milk fed to infant 1 were $3.52 \pm 0.01$ and $4.65 \pm 0.04$, respectively. The $\left[{ }^{13} \mathrm{C}\right]$ leucine and $\left[{ }^{15} \mathrm{~N}_{2}\right]$ lysine enrichments of lactoferrin in the pooled, fortified human milk fed to infant 2 were 3.23 \pm 0.008 and $1.65 \pm 0.057$, respectively.

Lactoferrin in the urine of human milk-fed preterm infants. Urine samples (8-h pools) collected from the two infants contained from 0 to $243 \mu \mathrm{g}$ of lactoferrin per $\mathrm{mL}$ (Table 2). Because the urines were diluted to varying degrees during the collection process, these values do not reflect actual urine concentrations. 
Table 2. Characteristics of human milk-fed preterm infant urines

\begin{tabular}{|c|c|c|c|c|c|}
\hline Urine pool no. & $\begin{array}{c}\text { Protein } \\
\text { concentration } \\
(\mathrm{mg} / \mathrm{mL})\end{array}$ & $\begin{array}{c}\text { Volume } \\
(\mathrm{mL})\end{array}$ & $\begin{array}{c}\text { Total protein } \\
(\mathrm{mg})\end{array}$ & $\begin{array}{c}\text { Lactoferrin } \\
(\mu \mathrm{g} / \mathrm{mL})\end{array}$ & $\begin{array}{c}\text { Total } \\
\text { lactoferrin } \\
(\mathrm{mg})\end{array}$ \\
\hline \multicolumn{6}{|l|}{ Infant 1} \\
\hline 1 & 3.14 & 50 & 157 & 10.38 & 0.519 \\
\hline 2 & 1.67 & 9 & 15 & 0.00 & 0.000 \\
\hline 3 & 4.58 & 70 & 320 & 1.45 & 0.101 \\
\hline 4 & 4.69 & 50 & 235 & 15.45 & 0.773 \\
\hline 5 & 1.98 & 105 & 207 & 3.73 & 0.392 \\
\hline 6 & 3.56 & 40 & 142 & 2.55 & 0.102 \\
\hline 7 & 2.80 & 70 & 196 & 21.39 & 1.497 \\
\hline 8 & 3.13 & 60 & 188 & 14.55 & 0.873 \\
\hline 9 & 3.02 & 70 & 211 & 30.31 & 2.123 \\
\hline 10 & 1.71 & 120 & 205 & 24.42 & 2.930 \\
\hline 11 & 3.19 & 80 & 255 & 10.18 & 0.814 \\
\hline 12 & 3.21 & 45 & 145 & 8.79 & 0.396 \\
\hline Total & & 769 & $2.28 \mathrm{~g}$ & & 10.5 \\
\hline \multicolumn{6}{|l|}{ Infant 2} \\
\hline 1 & 4.35 & 48 & 209 & 1.94 & 0.093 \\
\hline 2 & 4.00 & 60 & 240 & 16.13 & 0.968 \\
\hline 3 & 4.13 & 55 & 227 & 36.03 & 1.982 \\
\hline 4 & 4.59 & 58 & 266 & 74.50 & 4.321 \\
\hline 5 & 1.78 & 49 & 87 & 15.27 & 0.748 \\
\hline 6 & 3.56 & 47 & 167 & 44.31 & 2.083 \\
\hline 7 & 4.26 & 28 & 119 & 242.95 & 6.803 \\
\hline 8 & 2.26 & 129 & 292 & 97.26 & 12.547 \\
\hline 9 & 3.15 & 18 & 57 & 31.76 & 0.572 \\
\hline 10 & 3.22 & 28 & 90 & 1.30 & 0.036 \\
\hline 11 & 3.04 & 53 & 161 & 6.89 & 0.365 \\
\hline 12 & 2.75 & 81 & 223 & 18.34 & 1.486 \\
\hline Total & & 654 & $2.14 \mathrm{~g}$ & & 32.0 \\
\hline
\end{tabular}

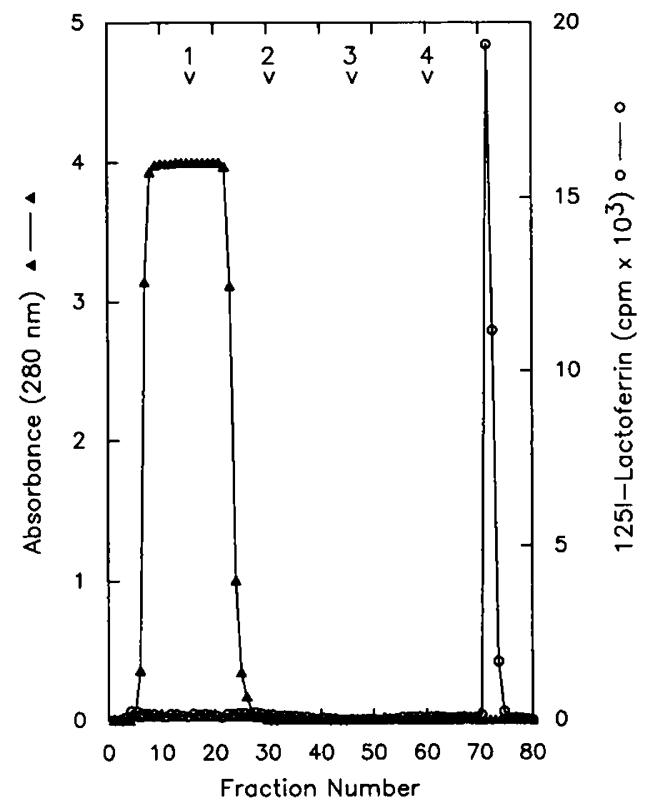

Fig. 2. Isolation of intact lactoferrin and DNA-binding lactoferrin fragments found in the urine of preterm infants fed human milk by affinity chromatography on ssDNA-agarose as described in Materials and Methods.

The total urinary outputs of lactoferrin, however, are provided in Table 2.

Purification and characterization of the urinary lactoferrin. The profile shown in Figure 2 illustrates the efficiency of ssDNA affinity columns for the one-step purification of intact lactoferrin and two major lactoferrin fragments from the urine of human milk-fed preterm infants. The majority of urinary protein detected by absorbance at $280 \mathrm{~nm}$ was eluted unretained in the

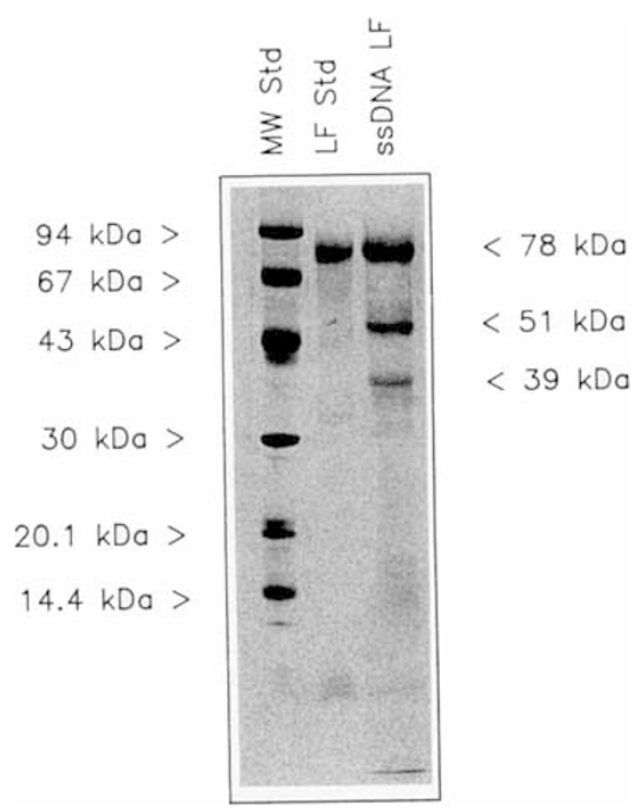

Fig. 3. SDS-PAGGE (10-20\%) of affinity-purified urinary lactoferrin under denaturing conditions. The migration patterns of the purified proteins were visualized by silver-staining. Lane 1 : calibrator proteins for the estimation of molecular mass (phosphorylase b, $94 \mathrm{kD}$; serum albumin, $67 \mathrm{kD}$; ovalbumin, $43 \mathrm{kD}$; carbonic anhydrase, $30 \mathrm{kD}$; soybean trypsin inhibitor, $20.1 \mathrm{kD}$; and $\alpha$-lactalbumin, $14.4 \mathrm{kD}$ ). Lane 2: purified lactoferrin obtained commercially. Lane 3: urinary lactoferrin purified by affinity chromatography on ssDNA-agarose (intact $78-\mathrm{kD}$ protein, 51 $\mathrm{kD}$ fragment, and 39-kD fragment). 


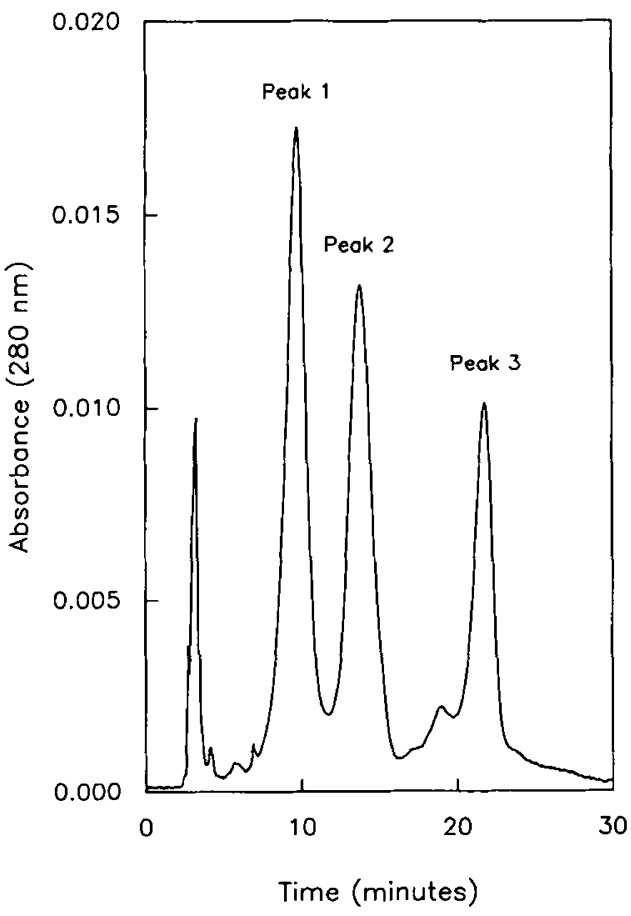

Fig. 4. Resolution of intact urinary lactoferrin and DNA-binding lactoferrin fragments ( 39 and $51 \mathrm{kD}$ ) by high-performance reverse-phase chromatography. Urinary lactoferrin and DNA-binding lactoferrin fragments were purified from urine by affinity chromatography on ssDNAagarose before analysis on phenyl reverse-phase columns using HFBA as the ion-pairing reagent. Peaks $1-3$ represent the $39-\mathrm{kD}$ fragment, $51-\mathrm{kD}$ fragment, and intact $78-\mathrm{kD}$ lactoferrin, respectively (see text). The profile shown is representative of 35 similar experiments. Details are provided in Materials and Methods.

flow-through fractions. The elution position of the absorbed urinary lactoferrin was typically not detectable by its absorbance at $280 \mathrm{~nm}$ alone. Thus, in separate experiments, the elution position and recovery of urinary lactoferrin were verified by the addition of trace quantities $(<5 \mathrm{pg})$ of $\left[{ }^{125} \mathrm{I}\right]$-labeled lactoferrin to test aliquots of preterm infant urines. Under the conditions specified, the recovery of lactoferrin was routinely $(n=50)$ greater than $90 \%$ and often near $100 \%$.

SDS-PAGGE of the urinary lactoferrin purified by ssDNAagarose affinity chromatography revealed the presence of proteins of 78,51 , and $39 \mathrm{kD}$ when the gel was silver-stained (Fig. 3 ). The presence of intact lactoferrin $(78 \mathrm{kD})$ was confirmed using polyclonal antisera to immunobiot the electrophoretic gels. Lower molecular weight lactoferrin fragments were also detectable. Using the more sensitive (detection limit 50 to $100 \mathrm{pg}$ ) lactoperoxidase and gold conjugate immunoblot detection systems as described previously $(30,40)$, these lower molecular mass (39- and 51-kD) proteins were also identified as immunoreactive lactoferrin. To determine their possible separate metabolic origins, the intact lactoferrin and its two DNA-binding fragments required separation before mass spectral analysis.

Separation of urinary lactoferrin fragments from intact lactoferrin. The efficient micropreparative separation of the intact urinary lactoferrin from the $51-$ and $39-\mathrm{kD}$ urinary lactoferrin fragments was achieved only by means of high-performance reverse-phase chromatography on phenyl-derivatized silica columns employing HFBA as the ion-pairing reagent. The profile shown in Figure 4 illustrates the elution pattern of urinary lactoferrin and lactoferrin fragments from one of the two infants fed labeled milk (the other preterm infant evaluated in this study produced urines that contained insufficient quantities of lactoferrin to justify further separation of fragments by this method). SDS-PAGGE and immunoblot analyses with anti-lactoferrin antibodies were used to confirm the identity of the three reverse-

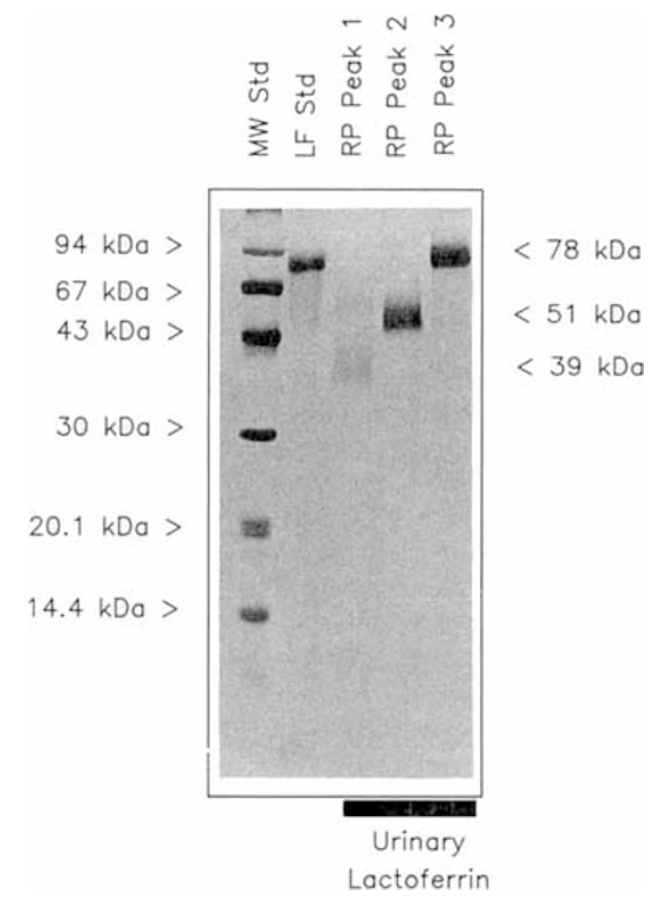

Fig. 5. Molecular mass evaluations and identification of intact urinary lactoferrin and the DNA-binding lactoferrin fragments isolated by affinity chromatography on ssDNA-agarose and resolved by high-performance reverse-phase chromatography. SDS-PAGGE of the affinity purified lactoferrin and lactoferrin fragments was performed after resolution of these lactoferrins by high-performance reverse-phase chromatography as described in Figure 4. Lane $l$ shows the migration pattern of the calibrator proteins used for estimation of molecular weight. Lane 2 shows the electrophoretic migration properties of human milk lactoferrin obtained from Jackson Immunoresearch Laboratories. Lane 3 illustrates the $39-\mathrm{kD}$ lactoferrin fragment present in peak 1 of the highperformance reverse-phase chromatographic elution profile shown in Figure 4. Lane 4 shows the electrophoretic migration profile of the 51$\mathrm{kD}$ lactoferrin fragment present in peak 2 of the high-performance reverse-phase chromatogram (Fig. 4). Lane 5 shows the electrophoretic migration profile of the intact lactoferrin present in peak 3 of the highperformance reverse-phase chromatogram (Fig. 4).

phase peaks. The SDS-PAGGE pattern in Figure 5 shows the intact lactoferrin as well as the two major DNA-binding fragments after their collective isolation by affinity chromatography on ssDNA-agarose and separation by high-performance reversephase chromatography. Immunoblot analyses confirmed the immunoreactivity of these proteins and led to the identification of the three reverse-phase peaks as the $39-\mathrm{kD}$ lactoferrin fragment, the 51-kD lactoferrin fragment, and intact lactoferrin, respectively. The isolated urinary lactoferrin (and fragments) recovered from each of the 128 -h urine pools were evaluated by GC-MS for isotopic enrichment.

Isotopic enrichment of urinary lactoferrin and its fragments. The profiles shown in Figure 6 demonstrate the rate and extent to which isotopically labeled lactoferrin appeared in the urine collected from each of the two preterm infants fed the labeled fortified human milk. In the case of subject 2 (Fig. $6 A$ and $B$ ), separate data are shown for the intact lactoferrin and the 39- and $51-\mathrm{kD}$ lactoferrin fragments isolated by reverse-phase chromatography. The horizontal line across the top of each profile indicates the isotopic enrichment of the lactoferrin present in the labeled, fortified milk that was fed to each of the two infants. The rate and extent of isotopic enrichment of the intact urinary lactoferrin $(78 \mathrm{kD})$, the $39-\mathrm{kD}$ urinary lactoferrin fragment, and the $51-\mathrm{kD}$ urinary lactoferrin fragment were quite similar. In each case, the isotopic enrichment of $\left[{ }^{13} \mathrm{C}\right]$ leucine (Fig. $6 \mathrm{~A}$ ) and $\left[{ }^{15} \mathrm{~N}_{2}\right]$ lysine (Fig. $6 B$ ) increased to a level equal to the isotopic 

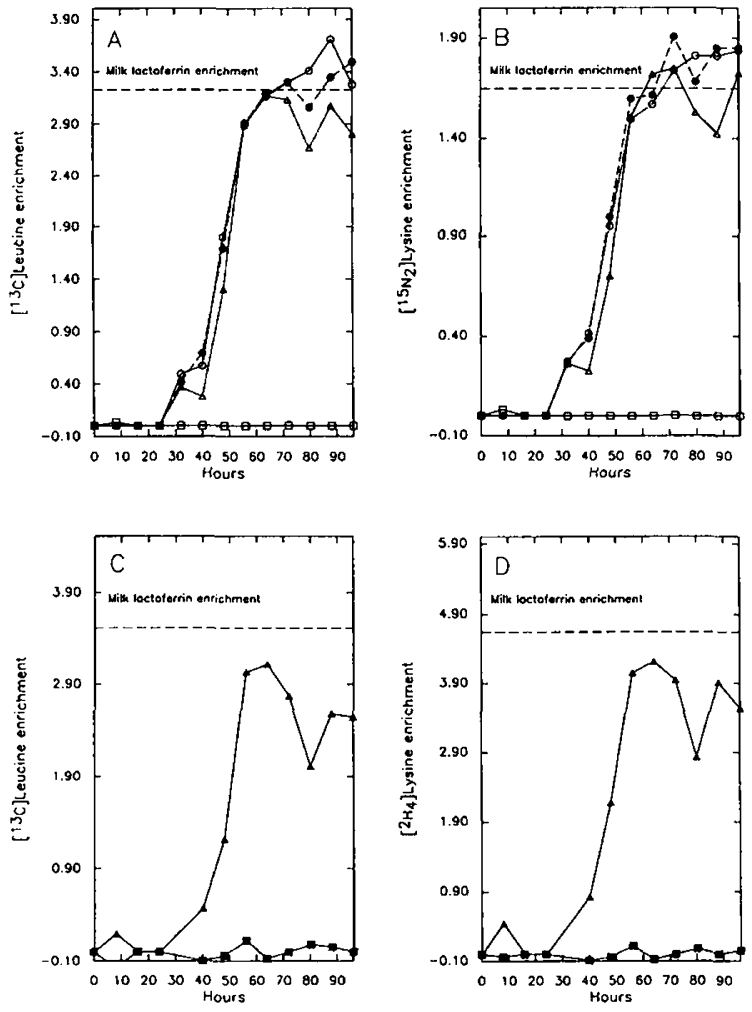

Fig. 6. Appearance of urinary lactoferrin enriched with the stable isotopes. Isotopic enrichments were determined as a function of time $(h)$ after introduction of labeled milk as described in Materials and Methods. The rate of $\left[{ }^{13} \mathrm{C}\right]$ leucine (panel $A$ ) and $\left[{ }^{15} \mathrm{~N}\right]$ lysine (panel $B$ ) accumulation in the preterm urinary lactoferrin (subject 2) is shown for the intact (78$\mathrm{kD}$ ) protein (open triangles), the $39-\mathrm{kD}$ fragment (open circles), and the $51-\mathrm{kD}$ fragment (filled circles). Panels $C$ and $D$ show the rate of $\left[{ }^{13} \mathrm{C}\right]$ leucine and $\left[{ }^{2} \mathrm{H}_{4}\right]$ lysine accumulation in the preterm urinary lactoferrin (closed triangles; intact lactoferrin and fragments) isolated from subject 1. The level of specific isotopic enrichment for lactoferrin purified from the human milk actually fed is shown by the dashed horizontal line near the top of each profile. Data points shown along the bottom of each profile indicate that $\left[{ }^{15} \mathrm{~N}_{2}\right]$ lysine (filled squares) and $\left[{ }^{2} \mathrm{H}_{4}\right]$ lysine (open squares), added as the free amino acid to the pooled, fortified milks from subjects 1 and 2, respectively, were not incorporated into the isolated urinary lactoferrin.

enrichment of the labeled lactoferrin in the fed milk; we observed comparable (87\%) degrees of isotopic enrichment in the intact urinary lactoferrin isolated from the urine of infant 1 (Fig. $6 \mathrm{C}$ and $D$ ). The maternal origin of the urinary lactoferrins from each preterm infant was established by comparison of the ratios of isotopically labeled leucine to lysine in the isolated milk and urinary lactoferrins. The ratio of $\left[{ }^{13} \mathrm{C}\right]$ leucine to $\left[{ }^{15} \mathrm{~N}_{2}\right] l y s i n e$ in the purified milk lactoferrin isolated from subject 2 (1.957) was similar to that in the purified urinary lactoferrin from her preterm infant (1.866). The ratio of $\left[{ }^{13} \mathrm{C}\right]$ leucine to $\left[{ }^{2} \mathrm{H}_{4}\right]$ lysine in the purified milk lactoferrin isolated from subject $1(0.756)$ was essentially the same as the ratio of these amino acids found in the purified urinary lactoferrin from her infant $(0.743)$. The possible endogenous synthesis of lactoferrin by the infant and, in particular, its appearance in the urine, was addressed by the addition of $\left[{ }^{15} \mathrm{~N}_{2}\right]$ lysine (subject 1 ) or $\left[{ }^{2} \mathrm{H}_{4}\right]$ lysine (subject 2 ) as the free amino acid to the pooled, fortified milks immediately before feeding. Neither $\left[{ }^{15} \mathrm{~N}_{2}\right]$ lysine (subject 1 ), nor $\left[{ }^{2} \mathrm{H}_{4}\right]$ lysine (subject 2) was detected in the purified urinary lactoferrins from either preterm infant (Fig. 6).

Relationship of urinary lactoferrin to total urinary protein. The concentrations of total urinary protein collected over the $96-\mathrm{h}$ period were similar for the two human milk-fed preterm infants studied during this investigation (Table 2). In contrast, however,

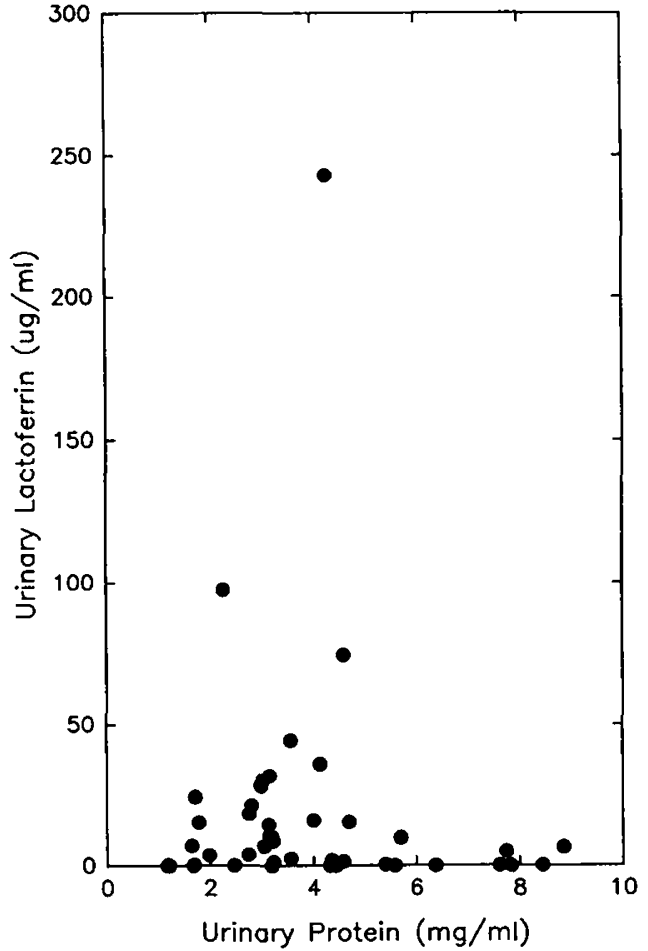

Fig. 7. Relationship between urinary lactoferrin concentrations and total urinary protein concentrations. Lactoferrin concentrations in the diluted urines were determined using enzyme-linked immunosorbent sandwich assays as described in Materials and Methods.

the quantities (total output) of urinary lactoferrin measured in these infants were quite different and varied significantly over the 96-h collection period (Table 2). The urinary lactoferrin concentrations were not related to total urinary protein concentrations (Fig. 7). Urinary lactoferrin and protein in the collected urine pools are given as concentrations in Figure 7; these concentrations reflect varying degrees of dilution associated with the routine urine collection procedures (29). The data presented in Table 2 for total urinary lactoferrin and protein outputs indicate that the lack of correlation between lactoferrin and protein was independent of the collection procedure (i.e. dilution).

\section{DISCUSSION}

Serum levels of lactoferrin in both preterm and term infants reportedly do not vary with diet (i.e. human milk versus bovine milk-based formula) $(22,24)$. As a result, the origin of biologically significant quantities of lactoferrin in the urine of preterm infants fed human milk has been the subject of much discussion (e.g. 21, 22). Because fecal excretion of lactoferrin accounts for only 1 to $6 \%(15-17)$ of the dietary lactoferrin in preterm infants, it has been suggested that much of the remaining lactoferrin is digested (14-18). This assumption remains untested. We have now demonstrated that nearly all of the intact lactoferrin in the urine of premature infants fed human milk is of maternal origin.

The similar ratios of labeled amino acids in the 78-kD lactoferrin purified from milk and preterm infant urine indicated that the labeled, intact lactoferrin excreted in urine by these infants was definitely of maternal origin; furthermore, the absolute levels of enrichment of $\left[{ }^{13} \mathrm{C}\right]$ leucine and $\left[{ }^{15} \mathrm{~N}_{2}\right]$ lysine or $\left[{ }^{2} \mathrm{H}_{4}\right]$ lysine in the urinary lactoferrin demonstrated that most (87 to $100 \%)$ of the recovered lactoferrin was of maternal origin. This conclusion is supported by our observation that the isotopically labeled free amino acid $\left[{ }^{2} \mathrm{H}_{4}\right]$ lysine or $\left[{ }^{15} \mathrm{~N}_{2}\right]$ lysine (added directly to the expressed, pooled milk samples) was not incorporated into either the intact urinary lactoferrin or its isolated fragments. Therefore, if endogenous lactoferrin was produced, it did not appear in their urine. 
The physiologic mechanisms that account for the uptake of intact lactoferrin by the gastrointestinal tract and its subsequent renal excretion were not addressed by these studies. The delay $(>24 \mathrm{~h})$ between the introduction of labeled lactoferrin and its appearance in urine was significant. The lack of a detectable association between urinary lactoferrin and total protein (either concentrations or total output) noted in the present study, and the significant correlations between the amounts of urinary immunologic factors excreted by preterm infants observed in previous studies (20) suggest that specific mechanisms are responsible for the presence of these proteins in urine. The question of selective protein excretion by infants who are fed human milk requires further analyses.

The urinary lactoferrin fragments are of considerable interest. These fragments, observed in at least eight different urine pools, were separated only under denaturing conditions in vitro. Under nondenaturing conditions, neither the $39-$ nor $51-\mathrm{kD}$ fragments were detected. The origin, nature, and regulation of the lactoferrin cleavage event(s) are not known. The indicated fragments were not detected in the milk of these mothers, in the milk of 10 other mothers that we studied (unpublished observations), or of others studied previously (21). These lactoferrin fragments that bind to DNA also are not detected in the milk of other mammals (bovine and porcine) we have studied (unpublished observations). It is therefore likely that these fragments arise from a limited or specific proteolysis either in the gastrointestinal tract, in the systemic circulation, and/or during filtration and excretion in the urine. Preliminary N-terminal sequence analysis of the purified $39-$ and $51-\mathrm{kD}$ fragments suggests that they represent portions of the N-lobe and the intact C-lobe of lactoferrin, respectively. The appearance of these two lactoferrin fragments only under denaturing conditions and always in a near 1:1 stoichiometry suggests that they are not totally separated in vivo, but complexed in a manner that sustains their association (41). The preserved DNA-binding properties of the intact lactoferrin and lactoferrin fragments imply that the DNA-binding domain of the lactoferrin molecule is relatively resistant to further proteolytic degradation.

The physiologic significance to preterm infants of absorbed, indegraded lactoferrin remains to be established. Its uptake may rroceed by nonspecific macromolecular absorption (42) or by way of association with specific lactoferrin receptors (43-49). Bennett and coworkers (7-9) have shown that the DNA-binding unctions of lactoferrin affect intercellular communications imong circulating lymphocytes, neutrophils, and granulocytes. Although the tertiary structure and function of the urinary actoferrin has not yet been documented, the ability of lactoferrin $o$ be absorbed in its intact form suggests that it may act in a egulatory capacity to influence the infant's developing immune iystem. The abilities of two relatively large (39- and 51-kD) JNA-binding fragments to resist further degradation and to enter he circulatory system otherwise intact suggest that they also may ict in a regulatory capacity. These findings suggest that at least $\mathrm{n}$ preterm infants who are fed human milk, lactoferrin may play broader biologic role than has been previously appreciated. ndeed, human milk lactoferrin does not appear to be a transient mmunoprotective protein localized to the gastrointestinal tract. he precise developmental period that may ultimately preclude he absorption and (or) renal excretion of intact lactoferrin (e.g. zrm infants) is currently under investigation.

Acknowledgments. The authors thank the volunteer mothers nd their infants for participation in this investigation; Pam iurns and the Texas Children's Hospital CRC staff for their elp; Laura Brown-Booth for her assistance with the mass specal analyses; E. Roseland Klein and Jerry D. Eastman from our ublications Department for their editorial assistance; and $\mathrm{Bu}$ rd L. Nichols, Wilson Pond, Peter Reeds, and Bruce Patterson )r helpful discussions and critical review of this manuscript.

\section{REFERENCES}

1. Woodhouse L, Lonnerdal B 1988 Quantitation of the major whey proteins in human milk, and development of a technique to isolate minor whey proteins. Nutr Res 8:853-864

2. Ainscough EW. Brodie AM, Plowman JE. Bloor SJ. Loehr JS, Loehr TM 1980 Studies on human lactoferrin by electronparamagnetic resonance, fluorescence, and raman spectroscopy. Biochemistry 19:4072-4079

3. Ainscough EW, Brodie AM, McLachlan SJ. Ritchie VS 1983 Spectroscopic studies on copper (II) complexes of human lactoferrin. J Inorg Biochem 18:103-112

4 Brock JH 1985 Transferrins. In: Harrison P (ed) Metalloproteins. Part 2: Metal Proteins with Non-Redox Roles. Topics in Molecular and Structural Biology, Vol 7. Verlag Chemie, Basel, pp 183-262

5. Nichols BL, McKee KS, Henry JF, Putman M 1987 Human lactoferrin stimulates thymidine incorporation into DNA of rat crypt cells. Pediatr Res 21:563-567

6. Azuma N, Mori H, Kaminogawa S, Yamauchi K 1989 Stimulatory effect of human lactoferrin on DNA synthesis in BALB/c 3 T3 cells. Agric Biol Chem $53: 31-35$

7. Bagby Jr GC, Rigas VD, Bennett RM, Vandenbark AA 1981 Interaction of lactoferrin, monocytes and $T$ lymphocyte subsets in the regulation of steadystate granulopoiesis in vitro. J Clin Invest 68:56-63

8. Bagby GC, Bennett RM 1982 Feedback regulation of granulopoiesis: polymerization of lactoferrin abrogates its ability to inhibit CSA production. Blood 60:108-112

9. Bennett RM, Davis J, Campbell S, Portnoff S 1983 Lactoferrin binds to cell membrane DNA. Association of surface DNA with an enriched population of B cells and monocytes. J Clin Invest 71:611-618

10. Beletskaya LV, Gnezditskaya EV 1985 Hetero-organic thymus antigens. Thymus 7:377-385

11. Gnezditskaya EV, Bukhova VP, Zakharova NA, Malkina LA 1987 Lactoferrininduced stimulation of $\mathrm{FC}_{\mu}$ and $\mathrm{Fc}$ receptor expression on the surface of human thymus lymphocytes in vitro. Byull Eksp Biol Med 103:447-449

12. Anderson BF, Baker HM, Rice DW, Baker EN 1989 The structure of human lactoferrin: crystallographic structure analysis and refinement at $2.8 \mathrm{~A}$ resolution. J Mol Biol 209:711-734

13. Anderson BF, Baker HM, Norris GE, Rumball SV. Baker EN 1990 Apolactoferrin structure demonstrates ligand-induced conformational change in transferrins. Nature 344:784-787

14. Davidson LA, Lonnerdal B 1985 Lactoferrin and secretory lgA in the feces of exclusively breast-fed infants. Am J Clin Nutr 41:852-861

15. Schanler R, Goldblum R, Garza C, Goldman AS 1986 Enhanced fecal excretion of selected immune factors in very low birthweight infants fed fortified human milk. Pediatr Res 20:711-715

16. Davidson LA. Lonnerdal B 1987 Persistence of human milk proteins in the breast-fed infant. Acta Paediatr Scand 76:733-740

17. Prentice A, Ewing G. Roberts SB, Lucas A, MacCarthy A. Jarjou LM. Whitehead RG 1987 The nutritional role of breast milk IgA and lactoferrin. Acta Paediatr Scand 76:592-598

18. Prentice A, MacCarthy A, Stirling DM, Vasquez-Velasquez L, Ceesay SM 1989 Breast milk lgA and lactoferrin survival in the gastrointestinal tracta study of rural Gambian children. Acta Paediatr Scand 78:505-512

19. Spik G, Burnet B, Mazurier-Dehaine C, Fontaine G, Montreuil J 1982 Characterization and properties of the human and bovine lactoferrins excreted from the feces of newborn infants. Acta Paediatr Scand 71:979-985

20. Goldblum RM, Schanler RJ, Garza C, Goldman AS 1985 Enhanced urinary lactoferrin excretion in premature infants fed human milk. Pediatr Res 19:342A(abstr)

21. Goldman AS, Garza C, Schanler RJ, Goldblum RM 1990 Molecular forms of lactoferrin in the stool and urine from infants fed human milk. Pediatr Res 27:252-255

22. Goldblum RM, Schanler RJ, Garza C, Goldman AS 1989 Human milk feeding enhances the urinary excretion of immunologic factors in low birth weight infants. Pediatr Res 25:184-188

23. Brenner BM, Dworkin LD, Ichikowa I 1986 Glomerular ultrafiltration. In: Brenner BM, Rector Jr FC (eds) The Kidney, Vol 1, WB Saunders Co. Philadelphia, pp. 124-144

24. Scott PH 1989 Enzyme immunoassay of lactoferrin in newborn term infants: reference values and influence of diet. Ann Clin Biochem 26:407-411

25. Scott PH 1989 Plasma lactoferrin levels in newborn preterm infants: effect of infection. Ann Clin Biochem 26:412-415

26. Hutchens TW, Magnuson JS, Yip T-T 1989 Interaction of human lactoferrin with DNA: one-step purification by affinity chromatography on singlestranded DNA-agarose. Pediatr Res 26:618-622

27. Hutchens TW, Henry JF, Yip T-T 1989 Purification and characterization of intact lactoferrin found in the urine of human milk-fed preterm infants. Clin Chem 35:1928-1933

28. Hopkinson J, Schanler RJ, Garza C 1988 Milk production by mothers of preterm infants. Pediatrics $81: 815-820$

29. Schanler RJ. Garza C. Nichols BL 1985 Fortified mother's milk for low birthweight infants: results of growth and nutrient balance studies. J Pediatr 107:437-448

30. Magnuson JS, Henry JF, Yip T-T. Hutchens TW 1990 Structural homology of human, bovine, and porcine milk lactoferrins: evidence for shared antigenic determinants. Pediatr Res 28:176-181

31. Smith PK. Krohn RI. Hermanson GT. Mallia AK. Gartner FH. Provenzano 
MD, Fujimoto EK, Goeke NM, Olson BJ, Klenk DC 1985 Measurement of protein using bicinchoninic acid. Anal Biochem 150:76-85

32. Marchalonis $J \mathbf{~} 1969$ An enzymic method for the iodination of immunoglobulins and other proteins. Biochem J 113:299-306

33. Hutchens TW, Magnuson JS, Yip T-T 1989 Purification of porcine colostral whey lactoferrin by affinity chromatography on single-stranded DNA-agarose. Characterization, amino acid composition and $\mathrm{N}$-terminal sequence analysis. Biochim Biophys Acta 999:323-330

34. Laemmli UK 1970 Cleavage of structural proteins during the assembly of the head of bacteriophage T4. Nature 227:680-685

35. Morrissey JH 1981 Silver stain for proteins in polyacrylamide gels: a modified procedure with enhanced uniform sensitivity. Anal Biochem 117:307-310

36. Burnette WN 1981 "Western blotting": electrophoretic transfer of proteins from sodium dodecyl sulfate-polyacrylamide gels to unmodified nitrocellulose and radioactive detection with antibody and radioiodinated protein $\mathrm{A}$. Anal Biochem 112:195-203

37. Irving CS, Thomas MR, Malphus EW, Marks L, Wong WW, Boutton TW, Klein PD 1986 Lysine and protein metabolism in young women. Subdivision based on the novel use of stable isotopic labels. J Clin Invest 77:1321-1331

38. Kropp DR 1979 Handbook of analytical derivatization reactions. John Wiley \& Sons, New York, pp 253-257

39. Hachey DL, Patterson BW, Ghiselli G, Marks L, Boriak J, Cook G, BrownBooth L, Gotto AM, Klein PD 1987 Long-term measurement of amino acid turnover and the synthesis of plasma apolipoproteins. In: Proceedings of the 35 th Annual Conference on Mass Spectrometry and Allied Topics, Denver, CO, May 24-29, 1987, pp 269-270
40. Bers G, Garfin D 1985 Protein and nucleic acid blotting and immunochemical detection. Biotechniques 3:276-288

41. Hutchens TW, Henry JF, Yip T-T 1991 Structurally intact (78-kDa) forms of maternal lactoferrin purified from the urine of preterm infants fed human milk: identification of a trypsin-like proteolytic cleavage event in vivo that does not result in fragment dissociation or loss of bound iron. Proc Nat Acad Sci USA (in press)

42. Axelsson I, Jakobsson I, Lindberg T, Polberger S, Benediktsson B, Raiha N 1989 Macromolecular absorption in term and preterm infants. Acta Paediatr Scand 78:532-537

43. Cox TM, Mazurier J, Spik G, Montreuil J, Peters TJ 1979 Iron binding proteins and influx of iron across the duodenal brush border. Evidence for specific lactoferrin receptors in the human intestine. Biochim Biophys Acta 588:120-128

44. Birgens HS, Hansen NE, Karle H, Kristensen LO 1983 Receptor binding of lactoferrin by human monocytes. Br J Haematol 54:383-391

45. Mazurier J, Montreuil J, Spik G 1985 Visualization of lactotransferrin brush border receptors by ligand-blotting. Biochim Biophys Act 821:453-460

46. Davidson LA, Lonnerdal B 1988 Specific binding of lactoferrin to brush-borde membrane: ontogeny and effect of glycan chain. Am J Physiol 254:G580G585

47. McKenna WR, Mickelsen PA, Sparling PF, Dyer DW 1988 Iron uptake from lactoferrin and transferrin. Infect Immun 56:785-791

48. Birgens HS, Ostergaard KL, Borregaard N, Karle H, Hansen NE 1988 Lactoferrin-mediated transfer of iron to intracellular ferritin in human monocytes. Eur J Haematol 41:52-57

49. Oria R, Alvarez-Hernandez X, Liceaga J, Brock JH 1988 Uptake and handling of iron from transferrin, lactoferrin and immune complexes by a macrophage cell line. Biochem J 251:221-225 